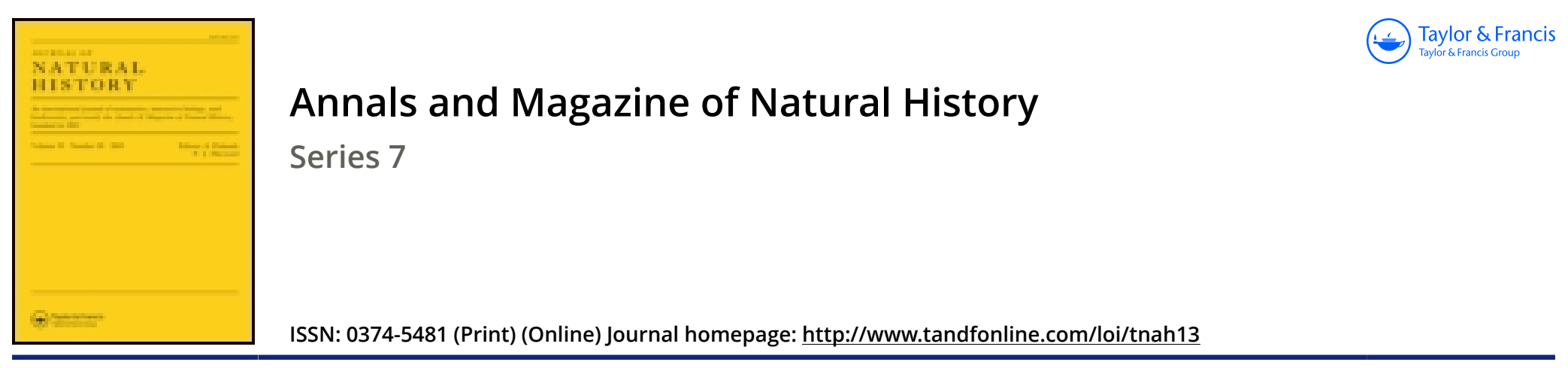

\title{
XXVIII.-The musk-rat of Santa Lucia (Antilles)
}

\section{C.I. Forsyth Major}

To cite this article: C.I. Forsyth Major (1901) XXVIII.-The musk-rat of Santa Lucia (Antilles), Annals and Magazine of Natural History, 7:38, 204-206, DOI: 10.1080/00222930108678460

To link to this article: http://dx.doi.org/10.1080/00222930108678460

册 Published online: 29 Sep 2009.

Submit your article to this journal $\asymp$

III Article views: 3

Q View related articles $₫$ 
XXVI.-Description of a new Gecko from the Niger Delta. By G. A. BOUlenger, F.R.S.

\section{Hemidactylus Ansorgii.}

Head elongate, once and three fourths as long as broad, not very distinct from neck; snout obtusely pointed, longer than the distance between the eye and the ear-opening; forehead slightly concave; ear-opening vertically oval, more than half the diameter of the eye. Body and limbs rather slender. Digits moderately elongate, free, normally formed, the inner rell developed; 5 lamella under the pollex, 8 under the fourth finger, 6 under the hallux, 11 under the fourth toe. Head covered with very small granules, which are larger on the snout; rostral four-sided, twice as broad as deep, with median cleft above; nostril pierced between the rostral, the first upper labial, and three nasals ; 11 upper and 12 lower labials ; symphysial triangular, twice as long as the adjacent labials; two pairs of chin-shields, the median pair forming a suture behind the symphysial. Upper surface of body covered with minute granules intermixed with small strongly keeled tubercles, forming 8 irregular longitudinal series; ventral scales quite as large as the dorsal tubercles, imbricate, smooth. No enlarged tubercles on the limbs. A short angular series of 9 præanal pores. Tail cylindrical, slender, covered above with small granules and transverse series of subconical tubercles, beneath with large, irregular, imbricate, smooth scales. Dark brown above, with some lighter spots; whitish beneath, finely speckled with brown.

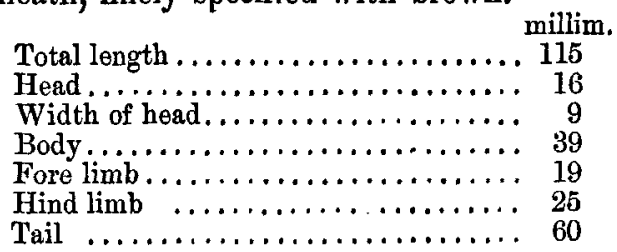

A single specimen from Sapele Station, Niger Delta ; presented to the British Museum by Dr. W. J. Ansorge.

\section{XXVII.-The Musk-Rat of Santa Lucia (Antilles). By C. I. Forsyth Major.}

THE obvious inference that the musk-rats of the Antilles pertain to the Hesperomyinz was first announced by the Secretary of the Zoological Society of London when registering a specimen from Santa Lucia amongst the additions 
to the menagerie*. Two years later Gosse remarks that the Mus pilorides of Desmarest, "found in the Caribbean Islands, has not the dentition of the Old-World rats, but resembles, in the structure of its molars, the South-American rats grouped by $\mathrm{Mr}$. Waterhouse under the generic name of Hesperomys" $t$.

From the published description and figures it is impossible to make more than a guess as to which group of Hesperomyinæ the musk-rats may belong; Winge was therefore right in saying that their closer relationship is still unknown.

The examination of a specimen from Santa Lucia in the British Museum (no. 53. 12. 16. 4), presumably the one mentioned in the P. Z. S. for 1849 , shows that we have to do with the genus Oryzomys. The same may be said of the Martinique musk-rat; one of the type specimens from Martinique, presented by Plee to the Paris Museum, has found its way to the Leyden Museum, and its skull was kindly lent to me by Dr. Jentink.

The detailed description, with figures, of these two skulls, together with the lower dentition of a third (extinct) species found by Prof. Gregory in a small ossiterous breccia of Barbuda, will be given in another place.

The following is the synonymy of the musk-rat from Martinique :-

\section{Oryzomys piloris (Zimmerm.).}

Rat musqué (Pilori), O. de Rochefort, Hist. Nat. et Morale des Iles Antilles de l'Amérique, p. $12 \pm$ (1658).

Musk Cary, Pennant, Syn. of Quadr. p. 247. no. 183 (1771); 3rd ed. ii. p. 97 (1793).

Cavia, Species obscura, Erxleben, Syst. Regni Anim., Mammalia, p. 357 (1777).

Castor Piloris, Zimmermann, Zool. geogr. p. 509 (1777).

Mus pilorides, Desmarest, Wict. Sc. Nat. t. xliv. p. $483(1826)$; Wagner, Schreber's Säugthiere, Suppl. iii. p. 444 (1843).

Mus Desmarestii, Fischer, Syn. Mammalium, p. 316 (1829).

Le Pilori, F. Cuvier (E. Geoffroy \& F. Cuvier), Hist. Nat. des Mammif. iv. pl. cclviii. (1830).

Hesperomys (Megalonys) pilorides, p. p., Trouessart, Le Naturaliste, no. 45, p. 5(1881); Anu. Sc. Nat., Zool. xix. Art. no. 5, p. 13 (1885).

Holochilus (Megalomys) pilorides, p. p., Trouessart, Catal. Mamm. p. 520 (1897).

Hab. Martinique.

* "Mus (Hesperomys) pilorides," Proc. Zool. Soc. London, 1849, p. 105 .

† P. H. Gosse, 'A Naturalist's Sojourn in Jamaica,' pp. 449, 450 (1851).

Ann. \& Mag. N, Hist. Ser. 7. Vol. vii. 
For the specimen of Santa Lucia a new specific name is here proposed :-

Oryzomys lucia, sp. n.

Ifus (Flesperomys) pilorides, Mitchtll, Proc. Zool. Soc. London, 1849, p. 105.

Hes;eromys (Megalomys) pilorides, p. p., Trouessart, opp. citt.

Holochilus (Megalumys) pilorides, p. p., Trouessart, opp. citt.

The Martinique specimens vary somewhat in their dimensions; all are of large size, the skull of the largest specimen, described by Trouessart, having a length of 70 millim.

The species of Santa Lucia is distinguished by its habitat, its smaller size, the conformation of the outer wall of the infraorbital foramen (the anterior margin of which is more convex forward than in U. piloris), and, lastly, by the coloration of the belly, which is white in Oryzomys piloris and nearly wholly brown, continuous with the upper colour, in O. lucice.

Measurements of Skulls and Molar Series.

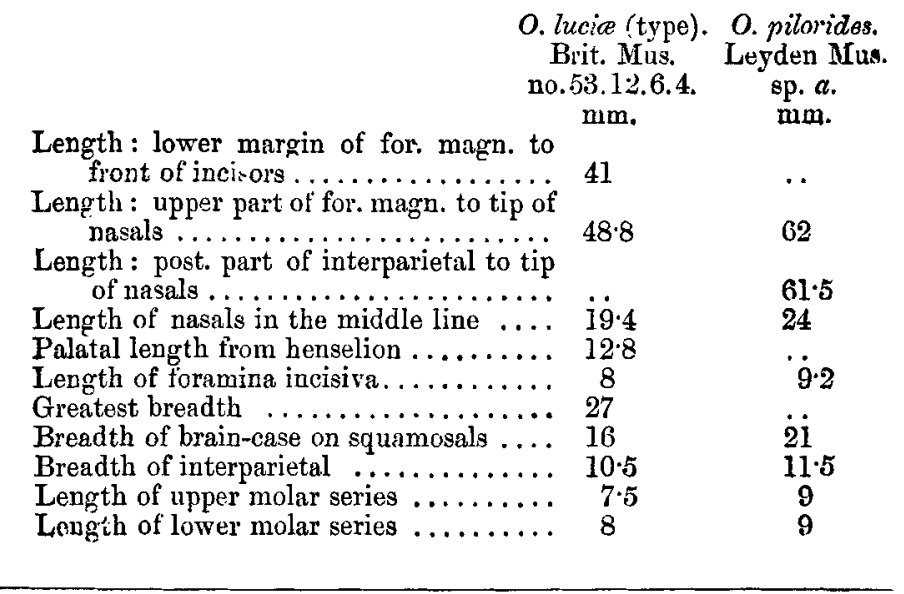

XXVIII.-Descriptions of Brazilian Coccidæ. By Adolph Hemper, S. Paulo, Brazil.

[Continued from p. 125.]

Subfamily LECANIINA.

Genus Lecanium, Illiger.

Lecanium brunfelsia, Hempel.

Adult female flat, subcircular in outline, reddish brown, with a double longitudinal row of five or six black oval spots 